\title{
Statistical modelling of biomarkers incorporating non-proportional effects for survival data
}

\author{
Jacqueline Stephen ${ }^{1 *}$, Gordon Murray ${ }^{1}$, John Bartlett ${ }^{2,3}$, David Cameron ${ }^{4}$ \\ From 2nd Clinical Trials Methodology Conference: Methodology Matters \\ Edinburgh, UK. 18-19 November 2013
}

Personalised medicine is replacing the one-drug-fits-all approach with many prognostic models incorporating biomarkers available for risk stratifying patients with breast cancer, such as the Nottingham Prognostic Index and Adjuvant! Online and more recently multiparameter assays, OncotypeDx and Mammaprint.

Evidence of biomarkers having non-proportional effects have been emerging and therefore violating the assumption of proportional hazards when performing Cox regression. A classic example is the risk of recurrence after breast cancer depends on the duration of follow-up for estrogen receptor (ER) and progesterone receptor (PgR) expression status[1]. The gene signature MammaPrint has also been shown to have possible nonproportional effects with better prediction of patients at high risk of early relapse rather than those at risk of later disease progression[2,3].

A review of existing approaches for the analysis of nonproportional effects with respect to survival data found there to be a number of well-developed approaches for incorporating non-proportional effects but a lack of application of these approaches in practice. Two key approaches are the multivariable fractional polynomial time (MFPT) approach by Sauerbrei et al.[4] and flexible parametric models proposed by Royston \& Parmer[5].

There is a need for more widespread use of flexible modelling to move away from standard analysis using a Cox model when the assumption of proportional hazards is violated. Fully determining the effects of markers in prognostic studies will help develop novel models for the selection of patients for appropriate treatments.

\section{Authors' details}

${ }^{1}$ University of Edinburgh, Edinburgh, UK. ${ }^{2}$ Ontario Institute for Cancer Research, Toronto, Canada. ${ }^{3}$ Endocrine Cancer Group, Edinburgh University

${ }^{1}$ University of Edinburgh, Edinburgh, UK

Full list of author information is available at the end of the article
Cancer Research Centre, Edinburgh, UK. ${ }^{4}$ Edinburgh Cancer Research Centre, Edinburgh, UK.

Published: 29 November 2013

\section{References}

1. Mulligan AM: Clinical Cancer Research 2008, 14:4168-4174.

2. Buyse M: Journal of the National Cancer Institute 2006, 98:1183-1192.

3. Desmedt C: Clinical Cancer Research 2007, 13:3207-3214.

4. Sauerbrei W: Biometrical Journal 2007, 49:453-473.

5. Royston P: Statistics in Medicine 2002, 21:2175-2197.

doi:10.1186/1745-6215-14-S1-P116

Cite this article as: Stephen et al.: Statistical modelling of biomarkers incorporating non-proportional effects for survival data. Trials 201314 (Suppl 1):P116.
Submit your next manuscript to BioMed Central and take full advantage of:

- Convenient online submission

- Thorough peer review

- No space constraints or color figure charges

- Immediate publication on acceptance

- Inclusion in PubMed, CAS, Scopus and Google Scholar

- Research which is freely available for redistribution
() Biomed Central 